\title{
INFLUÊNCIA DAS VARIÁVEIS ATMOSFÉRICAS NA DEGRADAÇÃO DOS MATERIAIS DA CONSTRUÇÃO CIVIL
}

\author{
Impact of atmospheric variables on the construction materials
}

\begin{abstract}
Rui Barbosa de Souza ${ }^{1}$, Michelle Simões Reboita ${ }^{2}$, Ana Paula Werle ${ }^{3}$, Eliane Betânia Carvalho Costa ${ }^{4}$
Recebido em 25 de maio de 2016; recebido para revisão em 18 de julho de 2016; aceito em 27 de julho de 2016; disponivel on-line em 31 de agosto de 2016.
\end{abstract}

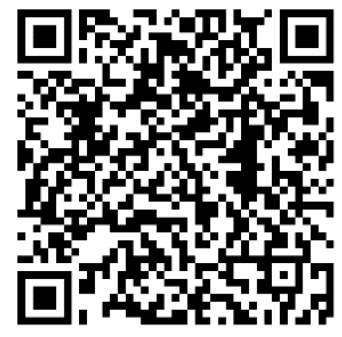

PALAVRAS CHAVE:

Variáveis atmosféricas;

Degradação;

Materiais da construção civil.

\section{KEYWORDS:}

Atmospheric variables;

Degradation;

Construction material.

\footnotetext{
* Contato com os autores:
}

${ }^{1}$ e-mail: rui.souza78@gmail.com

(R. B. Souza)

Eng. Civil, Dr. em Engenharia Civil, Docente da Fundação Educacional Inaciana Padre Sabóia de Medeiros (FEI).

2e-mail: reboita@gmail.com ( M. S. Reboita )

RESUMO: Este estudo apresenta uma revisão da literatura sobre o tema impacto de variáveis atmosféricas em materiais da construção civil. Ao longo do trabalho é apresentada a definição das variáveis atmosféricas e a relação destas com a degradação de materiais cerâmicos, metálicos, poliméricos e madeiras. Por exemplo, a temperatura do ar pode causar dilatação e retraimento em materiais cerâmicos causando o colapso desse material. Essa variável atmosférica também é responsável pela alteração estrutural de polímeros. Já os materiais metálicos sofrem corrosão pelo efeito da umidade do ar; nas madeiras, esta variável favorece o desenvolvimento de agentes biológicos degradadores. Por fim, destaca-se que este estudo serve de referência para graduandos em engenharia civil e arquitetura bem como para aqueles interessados no tema.

ABSTRACT: This study presents a review of literature on the subject impact of atmospheric variables in the construction materials. Throughout the paper, we present the definition of atmospheric variables and their relationship to the degradation of ceramic, metallic and polymeric materials and wood. For example, the air temperature can cause dilatation and retraction of ceramic materials causing the collapse of the material. This atmospheric variable is also responsible for structural polymers change. Metallic materials corrode by the humidity effect. While, in the woods, this variable favors the development of degrading biological agents. Finally, it is emphasized that this study serves as a reference for graduate students in civil engineering and architecture as well as for those interested in the topic.

\section{e-mail: anhapaula@gmail.com (A.P. Werle)}

Arquiteta Urbanista, Dra. em Eng. Civil, Pesquisadora do Dep. de Eng. de Construção Civil da Universidade de São Paulo (USP).

${ }^{4}$ e-mail: elianebetania@hotmail.com (E. B. C. Costa)

Engenheira Civil, Dra. em Eng. Civil, Docente do Curso de Engenharia Civil da Universidade Tecnológica Federal do Paraná (UTFPR). 


\section{INTRODUÇÃO}

As edificações são projetadas para uma vida útil mínima de 50 anos ${ }^{1}$, segundo a norma de desempenho NBR 15575 (ABNT, 2013), período que estas devem exercer suas funções como conforto, desempenho funcional e segurança. Com intuito de aumentar e garantir o tempo de vida útil previsto em projeto, as edificações devem contar com intervenções programadas de manutenção. Quando se tratam de obras de arte (pontes, viadutos etc.), estas são projetadas para um tempo maior de vida útil. A vida total de uma estrutura de construção civil é o resultado entre a degradação sofrida pelo uso e interação com o meio ambiente, e os incrementos de desempenho oriundos das intervenções de manutenção. $O$ resultado deste balanço representa a vida útil da construção (Figura 1).

$\mathrm{O}$ uso das edificações e outras estruturas de construção civil, bem como suas interações com o meio ambiente, interferem na vida útil. As operações de limpeza e manutenção, influência das variáveis atmosféricas e mudanças no entorno ao longo do tempo, podem alterar as características dos materiais e da qualidade da construção como um todo. Para que as construções atinjam a vida útil desejada, em função das soluções tecnológicas adotadas e, especialmente, dos materiais de construção empregados, é preciso que tenham durabilidade. A durabilidade é "a capacidade que um produto, componente ou construção possui de manter o seu desempenho acima dos níveis mínimos especificados, de maneira a atender as exigências dos usuários, em cada situação específica" (CIB W80/RILEM 71-PSL, 1983). A durabilidade está diretamente relacionada com as condições de exposição as quais a construção está submetida. Entende-se por condições de exposição o conjunto de influências ou ações atuantes sobre uma construção durante sua vida útil. Entre essas têm-se: choques, incêndios e as ações oriundas dos fenômenos de origem natural (vento, chuva, radiação solar, temperatura etc.).

De modo geral, as construções têm grande vida útil. Esta longevidade pode ser bem ilustrada através de exemplos de construções com grande durabilidade (Figura 2). Mesmo sendo construídas em épocas onde a tecnologia dos materiais e das construções não se encontrava nos padrões atuais de desenvolvimento, é comprovado que as construções podem ser muito duráveis. Como exemplos, citam-se o Coliseu Romano, inaugurado em 72 d.C.; ou os arcos da Lapa (Rio de Janeiro-RJ), inaugurado em 1723; e o teatro municipal de São Paulo, inaugurado em 1911; todas estas construções ainda resistem às ações do tempo. Outros exemplos de construções com elevada durabilidade também são expostos na Figura 2, e mostram que quando corretamente projetadas, especificadas e com correta execução das operações de manutenção, as construções podem atingir vida útil que atravessa gerações.

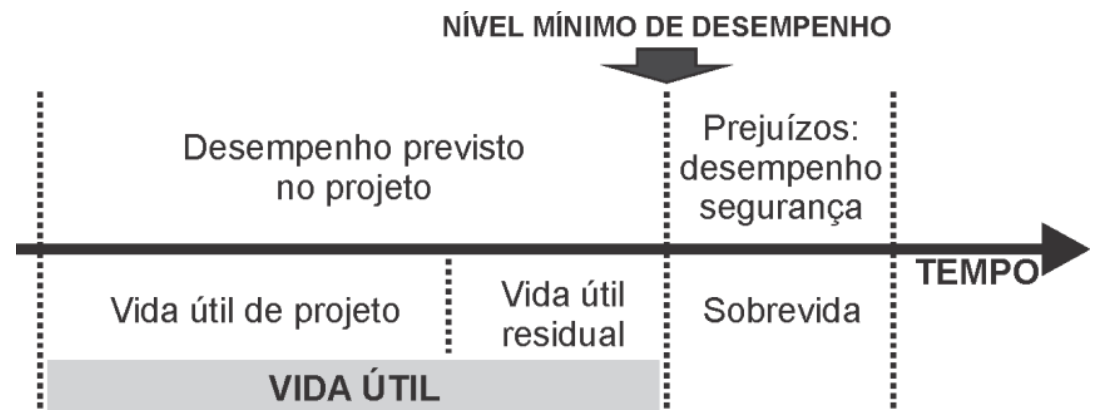

FIGURA 1: Desempenho de uma construção ao longo do tempo. FONTE: Adaptado de Mitidieri Filho (2007).

\footnotetext{
${ }^{1}$ A norma técnica ABNT NBR 15575 estabelece como vida útil mínima de projeto 50 anos para a estrutura de uma edificação, 13 anos para seus pisos internos, 40 anos para vedação vertical
}

externa e 20 anos para cobertura, entre outros sistemas que compõe uma edificação, também contemplados nesta norma. 


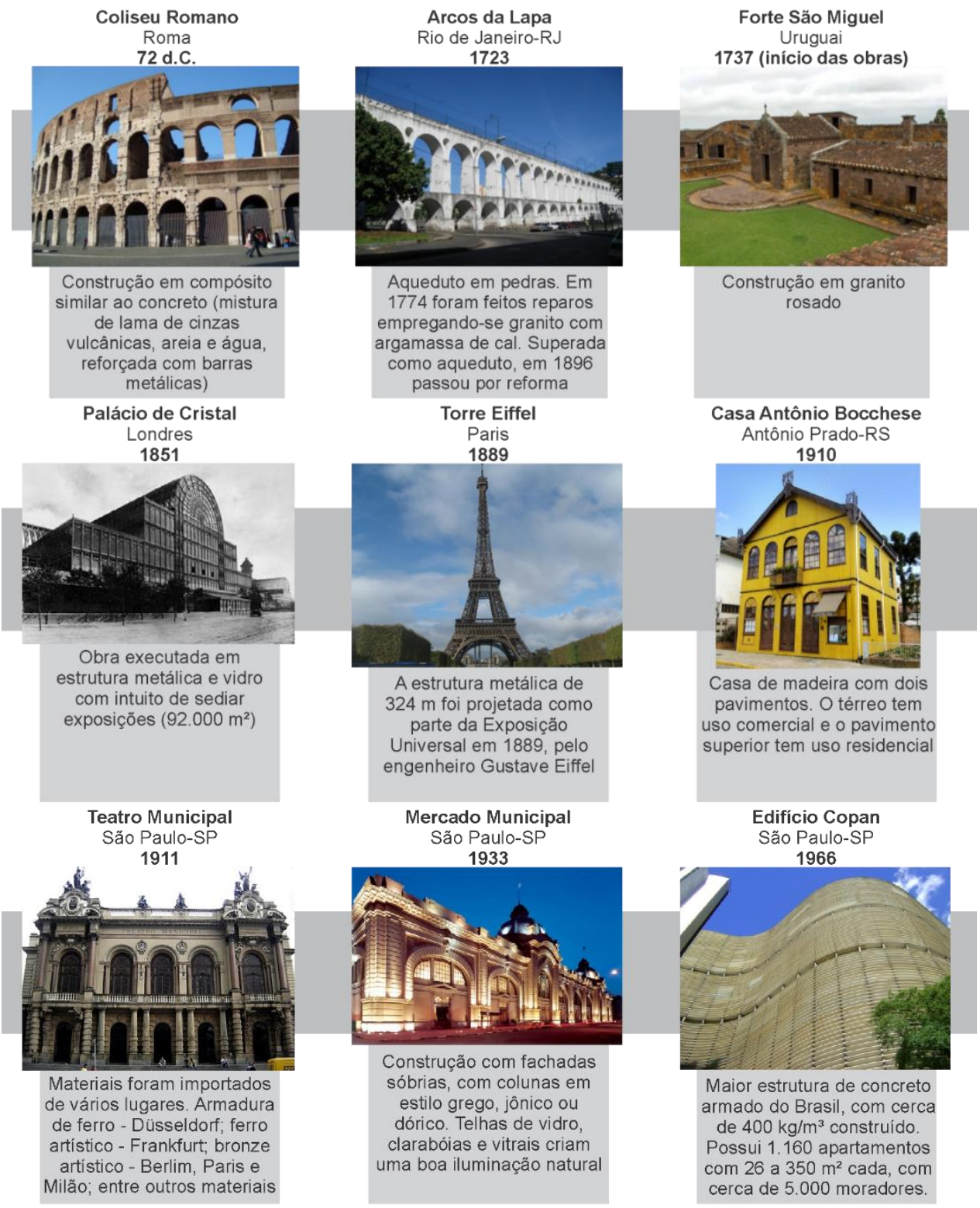

FIGURA 2: Construções com elevada durabilidade.

FONTE: Fotos são cortesias de Michelle Reboita (Coliseu Romano), Jerre Rocha (Forte São Miguel), Eliane Betânia (Torre Eiffel), Ana Paula Werle (Edifício Copan). Demais fotos foram obtidas das fontes http://www.panoramio.com/photo/10976630 (Arcos da Lapa), http://arquitetandonanet.blogspot.com.br/ (Palácio de Cristal), http://commons.wikimedia.org (Casa Antônio Bocchese), por André Bonacin em http://www.panoramio.com/photo/757359 (Teatro Municipal),

http://www.arcoweb.com.br/arquitetura/pedro-paulo-de-melo-saraiva-revitalizacao-de-17-11-2004.html (Mercado Municipal).

A influência das variáveis atmosféricas é um fator determinante na durabilidade dos materiais de construção e, consequentemente, dos edifícios. Por exemplo, em locais onde a amplitude térmica é elevada, os materiais são submetidos às variações dimensionais de origem térmica com maior intensidade, como é o caso da cidade de São Paulo, onde no mesmo dia a temperatura pode atingir valor mínimo em torno de $10^{\circ} \mathrm{C}$ e máximo superior a $20^{\circ} \mathrm{C}$. Locais com alternância de períodos ensolarados e com chuva resultam no mesmo cenário de variação volumétrica, além de favorecer a lixiviação e precipitação de sais em cerâmicas porosas. Há ainda situações peculiares associadas às variáveis atmosféricas, como nas regiões litorâneas. Nestes locais a elevada e constante umidade relativa do ar, aliada à grande concentração de sais, favorece a corrosão de alguns metais e a deterioração de materiais porosos. Locais com formação de neve e gelo requerem atenção especial na especificação de materiais porosos, pois estes estão sujeitos à ação expansiva da formação de gelo no interior dos poros. Em virtude dos exemplos citados, observa-se que são inúmeras as 
possibilidades e condições de exposição, tornando as variáveis atmosféricas parâmetros de fundamental importância no estudo da durabilidade dos materiais e projeto das construções.

\section{VARIÁVEIS ATMOSFÉRICAS}

As variáveis atmosféricas são abordadas no meio técnico da construção civil frequentemente de forma simplista e muitas vezes resumidas em uma única palavra: intempéries. Essa denominação não leva em consideração o efeito de cada variável atmosférica nos projetos de construções, o que pode propiciar erro de especificação e aplicação dos materiais de construção, uma vez que as diferentes variáveis atmosféricas causam diferentes solicitações às construções.

As variáveis atmosféricas que mais influenciam os materiais das construções são: radiação solar, temperatura do ar, umidade do ar, precipitação e vento.

Radiação solar: a radiação solar corresponde à energia proveniente do Sol, na forma de radiação eletromagnética, que atinge a superfície do planeta. De forma geral, todos os objetos emitem radiação eletromagnética que pode ser nas seguintes formas: radiação gama, raios- $X$, radiação ultravioleta, luz visível, radiação infravermelha, micro-ondas e ondas de rádio. Essas formas de radiação constituem o que se denomina de espectro eletromagnético (Figura 3), sendo que cerca da metade de toda a energia emitida pelo Sol é na frequência da luz visível (Figura 4). Cada uma das faixas de frequência da radiação eletromagnética interage com a matéria de maneira particular. Desta forma, a atividade humana utiliza-se destas interações de modo conveniente, nas diversas áreas do conhecimento. A radiação gama, raios- $X$ e ultravioleta podem ser produzidas artificialmente e são utilizadas na medicina. A radiação ultravioleta é um potente germicida, os raios- $X$ são usados como ferramenta de diagnóstico do corpo humano e a radiação gama juntamente com os raios- $X$ são usados no tratamento do câncer. Entretanto, a radiação solar não é sempre benéfica, pois a exposição excessiva a ela pode ser nociva à saúde, causando câncer e danos aos fetos.

Uma vez que a função primordial da maioria das construções é dar abrigo e proteção ao ser humano, estas ficam expostas às variáveis atmosféricas constantemente. A radiação solar, com suas mais diversas faixas de frequência, interage com os materiais utilizados na construção civil, podendo causar impactos negativos na durabilidade e vida útil das construções. Por exemplo, os polímeros sintéticos e as madeiras (estas, que são materiais naturais utilizados na construção desde os primórdios), são afetadas pela radiação ultravioleta que altera suas propriedades mecânicas diminuindo o seu tempo de vida útil (ANDRADY et al., 1998). De forma geral, a radiação solar ao interagir com muitos materiais, causa transformações irreversíveis e leva à redução do tempo de vida útil destes.

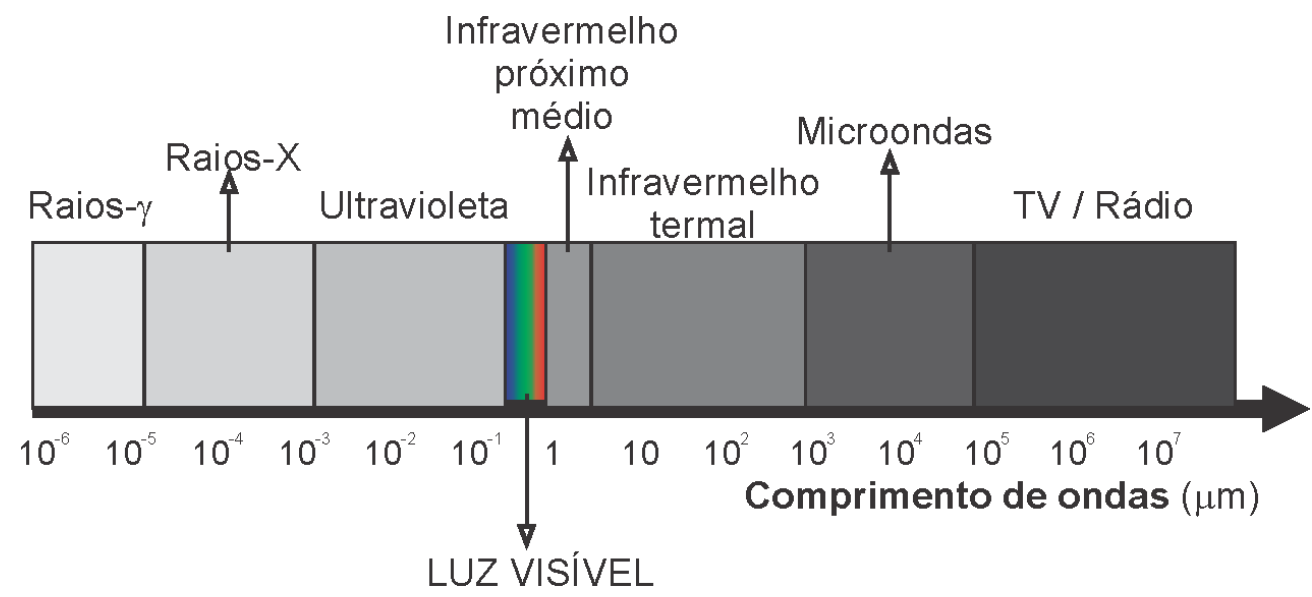

FIGURA 3: Espectro eletromagnético mostrando o nome e comprimento das ondas (em micrômetros) emitidas pelo Sol. FONTE: Adaptada de Liou (2002). 


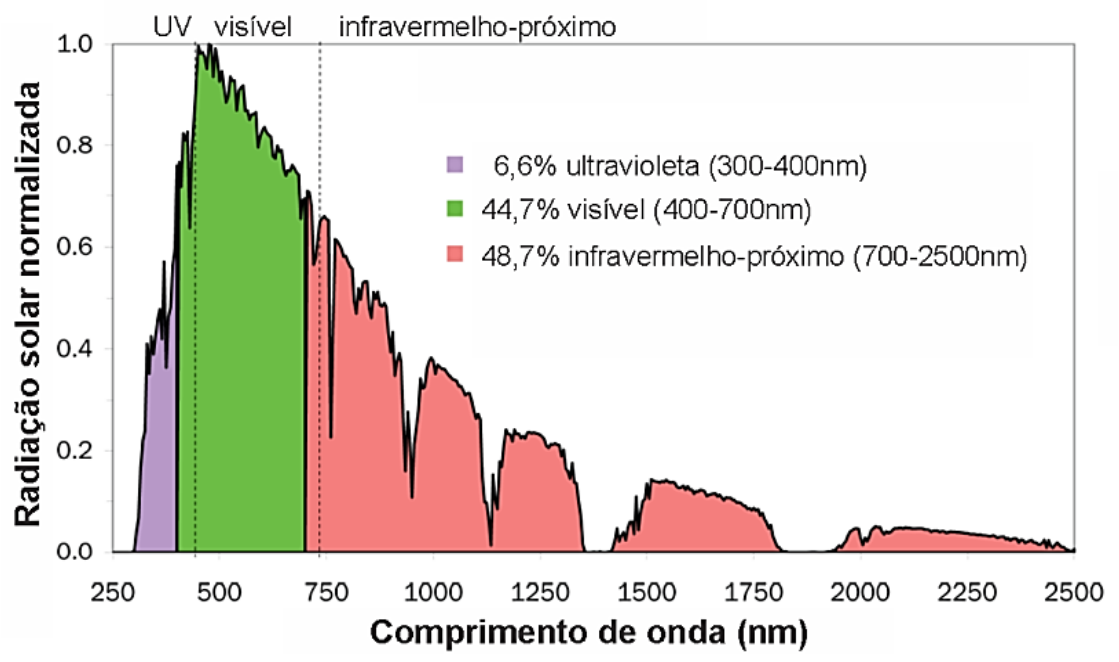

FIGURA 4: Espectro de radiação solar que atinge a superfície da Terra. FONTE: Adaptada de Liou (2002).

Temperatura do ar: cerca de $50 \%$ da radiação solar, que entra na atmosfera terrestre, atinge a superfície do planeta e a aquece. Posteriormente, ocorre o aquecimento das camadas de ar sobrejacentes à superfície (atmosfera) através dos processos de condução, convecção e radiação de energia proveniente da superfície do planeta (essa, por sua vez, é chamada de radiação terrestre) que foi aquecida pela energia solar. Se a atmosfera aquece isso significa que sua temperatura aumenta. A temperatura do ar é uma propriedade física que indica a energia cinética das moléculas de ar. Quando a temperatura do ar é maior do que a dos materiais (objetos) que o ar circunda, ocorre a transferência de energia para esses, já quando é mais fria, recebe energia desses. É importante ressaltar que tanto a radiação solar quanto a terrestre, ao incidir sobre os materiais da construção civil, podem aquecê-los. Muitos materiais empregados na construção civil, ao sofrerem contração e dilatação em virtude das variações de temperatura, podem apresentar manifestações patológicas, como fissuras. Uma das causas de variação de temperatura deve-se à alternância entre o dia e a noite. Durante o dia, a Terra recebe energia solar e se aquece; porém à noite, além de não receber energia solar, ainda perde a energia armazenada na sua superfície e atmosfera para o espaço, resfriando-se.

Umidade do ar: a temperatura do ar influencia diretamente a umidade do ar, pois quanto maior a temperatura maior é a capacidade do ar em manter vapor d'água. Portanto, locais com clima quente podem possuir uma atmosfera mais úmida do que os locais com clima frio. A massa de vapor d'água por quilograma de ar é denominada de umidade específica. Entretanto, outra maneira de expressar a umidade atmosférica é através da umidade relativa do ar. Essa é uma grandeza que indica quanto vapor d'água ainda é necessário para o ar atingir a saturação, ou seja, para estar com todo o conteúdo de vapor d'água que pode manter (100\%). Regiões do planeta com atmosfera constantemente úmida podem sofrer com proliferação de fungos que causam o apodrecimento de utensílios de madeira e processos químicos que corroem o aço. A corrosão, degradação dos componentes metálicos, resulta em prejuízos econômicos decorrentes da reposição de peças, interrupção das obras, dentre outros. Segundo Brusamarello et al. (2002), países industrializados como os Estados Unidos apresentam prejuízos da ordem de 300 bilhões de dólares anuais associados com problemas de corrosão o que supera catástrofes como enchentes e queimadas. Já Rieder et al. (2009) mencionam que no Brasil, apesar de não existirem estudos completos sobre os prejuízos causados pela corrosão, estima-se prejuízos superiores a 30 bilhões de dólares anuais.

Precipitação: Quando o vapor d'água é transportado verticalmente na atmosfera, pode propiciar a formação de nuvens. Inicialmente, o ar que se eleva na atmosfera sofre resfriamento e 
atinge a saturação. Então, o vapor d'água pode condensar em inúmeras e minúsculas gotículas que se agregam ao redor de pequenos núcleos chamados núcleos de condensação. Esses núcleos podem ser pólen, cristais de sal marinho etc. As nuvens que se localizam em alturas muito elevadas na atmosfera (acima de $7 \mathrm{~km}$, por exemplo) também podem ser formadas por cristais de gelo. Quando o peso da gotícula de nuvem excede a força de empuxo na atmosfera ela precipita. Nesse processo, a gotícula passa a ser chamada de gota de chuva. $A$ chuva, assim como a umidade do ar, causa danos aos materiais da construção civil tais como processos de corrosão. Os efeitos de corrosão podem ser intensificados em locais onde ocorre chuva ácida.

Em geral, a chuva é ácida ( $\mathrm{pH}$ médio de $5,6)$ devido à presença de dióxido de carbono $\left(\mathrm{CO}_{2}\right)$ na atmosfera que se dissolve nas gotas de chuva. Como $\mathrm{O} \mathrm{CO}_{2}$ está se tornado mais abundante na atmosfera, em função das atividades humanas que envolvem desmatamento, queima de combustíveis fósseis etc., a chuva tem se tornado mais ácida (isto é, com $\mathrm{pH}$ inferior a 5,6). Além disso, os óxidos de enxofre e de nitrogênio, também emitidos pelas atividades humanas, formam ácidos fortes, aumentando a acidez da água da chuva. A chuva ácida promove muitos efeitos negativos como redução da fertilidade do solo devido à liberação de substâncias tóxicas como o alumínio, desgaste de materiais da construção civil entre outros problemas. A Figura 5 mostra o efeito da chuva ácida sobre uma estátua de arenito na Alemanha. Após 60 anos a estátua sofreu um grande desgaste.

Vento: regiões da superfície terrestre com diferentes temperaturas também estão associadas com diferentes pressões. A variação horizontal da pressão atmosférica favorece o aparecimento da força do gradiente de pressão (FGP) a qual se dirige da maior para a menor pressão gerando os ventos. Assim, a FGP é a única força capaz de produzir ventos. Os ventos também trazem impactos negativos para os materiais da construção civil, pois transportam elementos que podem ser agressivos para os materiais; principalmente em regiões em que os ventos são constantes.

Um resumo dos impactos das variáveis atmosféricas nos materiais da construção civil é apresentado na Figura 6.
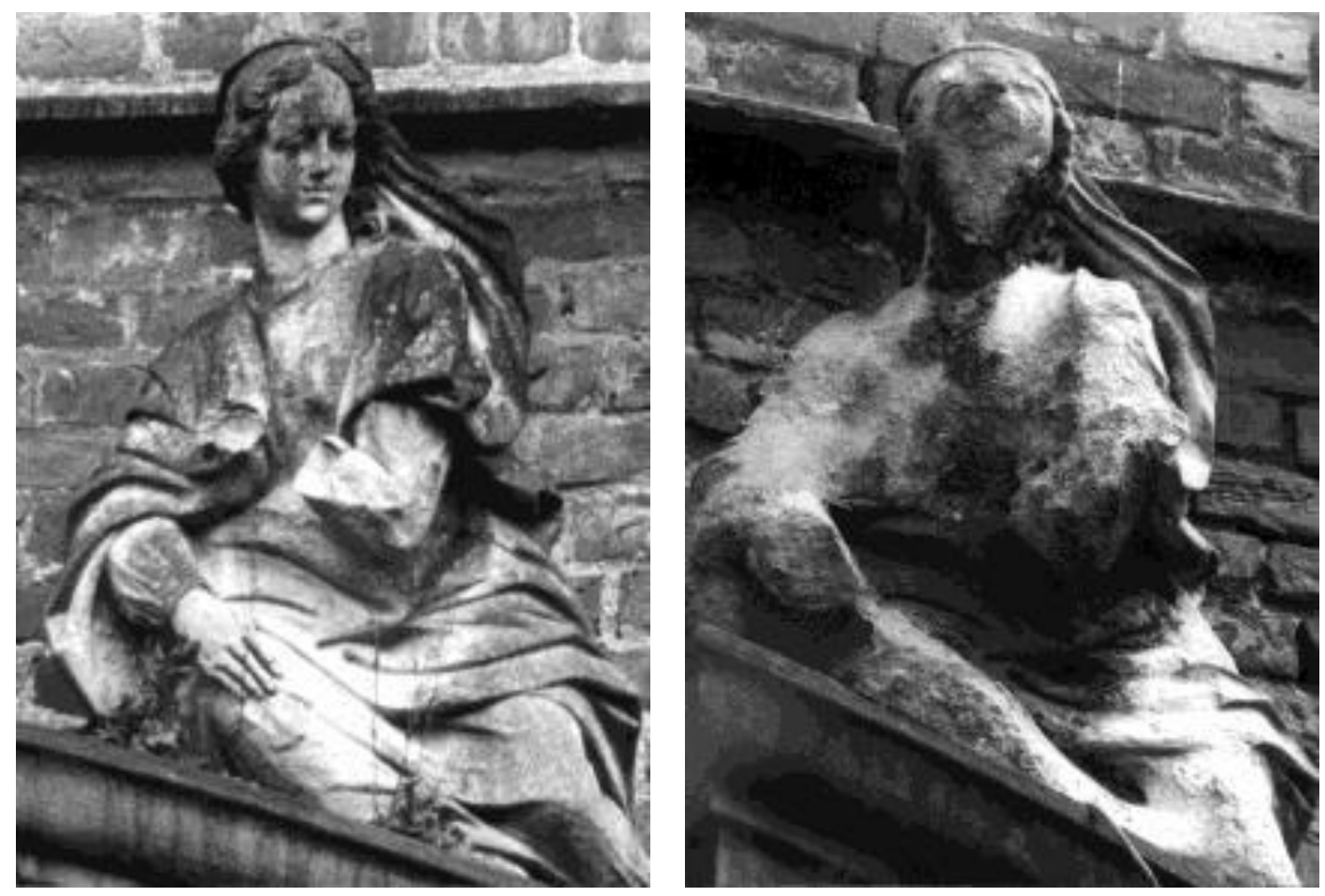

FIGURA 5: Efeito da chuva ácida após 60 anos de exposição de uma estátua de arenito sobre o portal de um castelo em Westphalia, Alemanha, fotografado em 1908 (esquerda) e novamente em 1968 (direita). FONTE: http://users.rcn.com/jkimball.ma.ultranet/BiologyPages/W/Westphalia_R.jpg. 


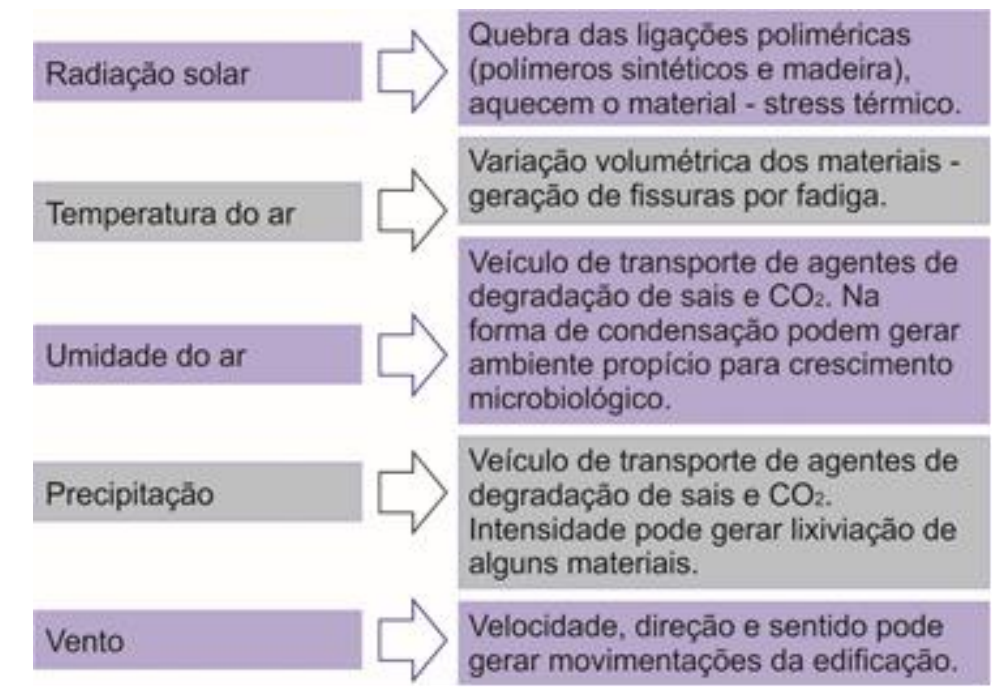

FIGURA 6: Degraação causada nas construções pelas variáveis atmosféricas. FONTE: Autoria própria.

\section{ATUAÇÃO DAS VARIÁVEIS ATMOSFÉRICAS} NA DEGRADAÇÃO DOS MATERIAIS DE CONSTRUÇÃO

$\mathrm{Na}$ engenharia, de modo geral, os materiais de construção são analisados como um todo contínuo e homogêneo, assumindo-se propriedades médias para a totalidade do volume considerado (ISAIA, 2007). Este é o enfoque tradicional da resistência dos materiais, em que são abordadas as propriedades mecânicas, como resistência dos corpos-de-prova, aproximando-se das condições reais empregadas em escala estrutural. Entretanto, as propriedades dos materiais e o seu desempenho em uso estão diretamente relacionados com a sua estrutura de formação, em nível de ciência dos materiais. A ciência dos materiais realiza a investigação das correlações que existem entre a estrutura e as propriedades de um material, enquanto que a engenharia de materiais, com base nestas correlações estrutura-propriedades, projeta um produto que contenha um determinado conjunto de características (CALLISTER JR. et al., 2008; ISAIA, 2007). Considerando a estrutura dos materiais, juntamente com suas propriedades, todo material sólido utilizado na construção pode ser classificado como: cerâmica, metal e polímero.

As cerâmicas são formadas por espécies químicas metálicas e não-metálicas, com ligações iônicas e covalentes, cujos elétrons estão ligados em posições definidas e fixas, o que Ihes confere propriedades características, como: isolantes de eletricidade, isolantes de calor, elevada resistência mecânica e, reduzida deformação plástica e elástica. As cerâmicas são, em geral, duras e frágeis, pois suas ligações moleculares são primárias, do tipo iônica (625 a $1550 \mathrm{~kJ} / \mathrm{mol}$ ) e/ou covalente (520 a $1250 \mathrm{~kJ} / \mathrm{mol}$ ), com um arranjo cristalino tetraédrico, que possui geometria de grande estabilidade. A alta energia de ligação se reflete em materiais muito resistentes. As ligações iônicas e covalentes são muito estáveis quimicamente, o que torna as cerâmicas matérias muito estáveis e inertes quimicamente, por este motivo as cerâmicas possuem elevada durabilidade. A energia de ligação das cerâmicas é muitas vezes superior a dos metais, por esse motivo, as cerâmicas têm potencial de atingir maior resistência que os metais. No entanto, na construção civil as cerâmicas utilizadas são porosas, como nos casos dos pisos, telhas etc. Embora as cerâmicas tenham grande potencial de resistência mecânica, a grande quantidade de poros impacta na redução desta resistência.

Os materiais metálicos são normalmente uma combinação de elementos metálicos. Eles possuem grande número de elétrons não localizados (estes elétrons não estão amarrados a átomos particulares). A ligação química molecular é primária, do tipo metálica, cuja energia de ligação é de alta magnitude (100 a $800 \mathrm{~kJ} / \mathrm{mol})$; por esse 
motivo, os metais possuem elevada resistência mecânica. As suas propriedades, incluindo a durabilidade em função das variáveis atmosféricas atuantes, são diretamente atribuídas a estes elétrons livres, podendo ser listadas como propriedades importantes: bons condutores de eletricidade, bons condutores de calor, elevada resistência mecânica e, elevada deformação plástica e elástica. Os elétrons livres transferem carga elétrica e energia térmica com facilidade, refletindo em boa condutividade. Estes mesmos elétrons livres tornam as moléculas que compõe os metais mais suscetíveis à interação com outros elementos químicos, como o oxigênio do ar, o que pode desencadear processos de oxidação e corrosão, impactando na durabilidade do material.

Os polímeros são macromoléculas orgânicas formadas pela união de substâncias simples, chamadas meros, que formam moléculas de cadeia longa com grupos repetitivos e que apresentam ligações covalentes. Os principais elementos destas cadeias são: carbono, hidrogênio, oxigênio, nitrogênio e outros elementos nãometálicos. As cadeias poliméricas se unem entre si por ligações secundárias (forças de Van der Waals), cuja energia de ligação tem menor magnitude (<40 kJ/mol). Esta estrutura confere propriedades como: baixa resistência mecânica e baixa densidade. Os polímeros podem ser pouco dúcteis e normalmente são pobres condutores elétricos. No entanto, quando ocorre predominância das ligações secundárias, estes podem ter sua ductilidade aumentada, com consequente queda de resistência. A baixa energia de ligação e o baixo ponto de fusão, tornam os polímeros, dentre os materiais usados na construção, aqueles com menor durabilidade, pois suas interações com as variáveis atmosféricas são mais intensas.

\subsection{MATERIAIS DE CONSTRUÇÃO CERÂMICOS}

Os elementos cerâmicos são largamente utilizados na construção, como o concreto das estruturas, os materiais de revestimento que podem ser argamassa e placas planas de cerâmica branca, elementos de vedação como os tijolos e blocos de cerâmica vermelha, vidros utilizados nos caixilhos, coberturas de fibrocimento ou telhas de cerâmica vermelha, entre outros.

Dentre os materiais utilizados na construção, as cerâmicas são aqueles com maior durabilidade, ou seja, com maior resistência à ação das variáveis atmosféricas. Isso é decorrente de sua formação cristalina, com ligações primárias estáveis e resistentes. Por outro lado, as cerâmicas utilizadas na construção são porosas, o que impacta sua durabilidade. Dentre as variáveis atmosféricas, aquelas que mais influenciam a durabilidade das cerâmicas são a radiação solar e temperatura do ar. Estas modificam a temperatura do material, bem como contribuem para a variação da umidade do ar que influencia a umidade nos poros do material. Além disso, associado aos processos termodinâmicos da atmosfera, tem-se a precipitação que impacta tanto na umidade nos poros quanto no transporte de agentes agressivos para o interior do material (Figura 7).

A temperatura do material influência diretamente sua variação dimensional, dilatando a cerâmica no aquecimento e retraindo no esfriamento. $\mathrm{O}$ coeficiente de dilatação térmica das

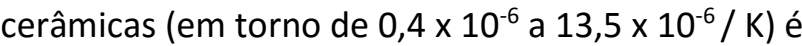
o menor em comparação com os metais (em torno de $4,5 \times 10^{-6}$ a $23,6 \times 10^{-6} / \mathrm{K}$ ) e os polímeros (em torno de $90 \times 10^{-6}$ a $216 \times 10^{-6} / \mathrm{K}$ ) (CALLISTER Jr et al., 2008). No entanto, a sua característica frágil faz com que a cerâmica não resista a estas deformações, entrando em colapso.

Como a ação da radiação solar e a temperatura do ar atuam especialmente no aumento da temperatura dos elementos cerâmicos, causando expansão dos mesmos, estes elementos necessitam de juntas de dilatação previstas na sua tecnologia de aplicação, como os rejuntamentos entre as placas cerâmicas de revestimento. As estruturas de concreto, as placas planas aderidas e não-aderidas, os vidros, em resumo, todos os elementos cerâmicos que não trabalham soltos, necessitam de juntas de dilatação para suportarem a deformação devido às variações de temperatura. Caso contrário, a variação volumétrica das cerâmicas pode ocasionar fissuras, destacamento dos elementos, e até mesmo quebra (colapso). 


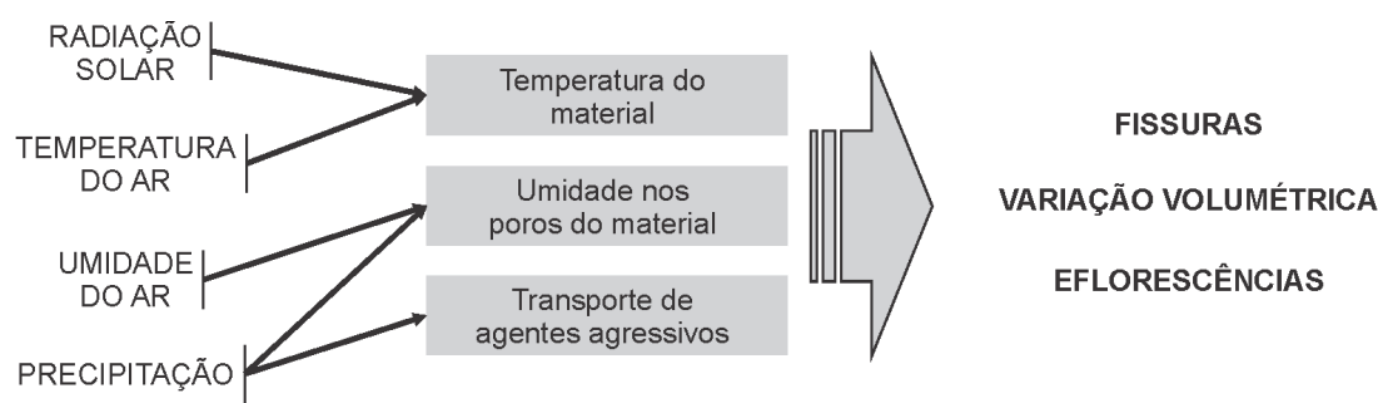

FIGURA7: Ação das variáveis atmosféricas no desempenho dos materiais cerâmicos. FONTE: Autoria própria.

A umidade presente no interior dos poros das cerâmicas também é fonte de variação volumétrica dos elementos. A retração, que ocorre devido à perda de água condensada no interior do poro de dimensão capilar dentro de material cerâmico, está fundamentada no efeito físico de depressão capilar (SOUZA, 2014). A pressão capilar, que é a pressão dentro dos poros capilares, exerce uma força de atração entre as superfícies das paredes do capilar, ou outras superfícies separadas por uma camada fina de água. Esta pressão capilar é significativa somente em poros com diâmetros inferiores a $50 \mathrm{~nm}$ (MINDESS, 1981). Este fenômeno pode ser descrito como uma tensão gerada nos poros capilares da cerâmica, devido à formação de um menisco no interior destes poros capilares quando são sujeitos à secagem (IDIART, 2009). A equação de Kelvin explica como a forma do menisco se configura com a variação da umidade relativa, e está fundamentada nos conceitos de ângulo de contato, tensão superficial e equação de Laplace.

O ângulo de contato é resultante do equilíbrio de forças entre as moléculas do líquido (forças coesivas) e entre as moléculas do líquido e a superfície (forças adesivas). Superfície composta por grupos polares terá uma boa afinidade com a água e, por conseguinte, forças adesivas intensas e um ângulo de contato reduzido (superfície hidrófila) (Figura 8a). Superfície constituída por grupos não polares (superfície hidrófoba), o ângulo de contato é grande (Figura 8b) (BARNES, 2011).

As forças de atração atuantes nas moléculas de água, quando estas estão na superfície, encontram-se em uma condição de desequilíbrio, devido à escassez de moléculas adjacentes na direção da fase gasosa, o que se reflete em uma força resultante (Figura 9). Como consequência, ocorre uma tendência de movimentação das moléculas da superfície na direção e sentido da força resultante, para o interior da massa de água. A força que tende a minimizar a área da superfície, equilibrando a força resultante citada, é a tensão superficial ( $($ ), que atua na direção tangencial à superfície (BARNES, 2011). Dentro de um poro capilar esta curvatura da superfície é chamada de menisco, e está sujeita à ação de outras forças decorrentes do ângulo de contato entre as fases líquida, gasosa e sólida (paredes do menisco).

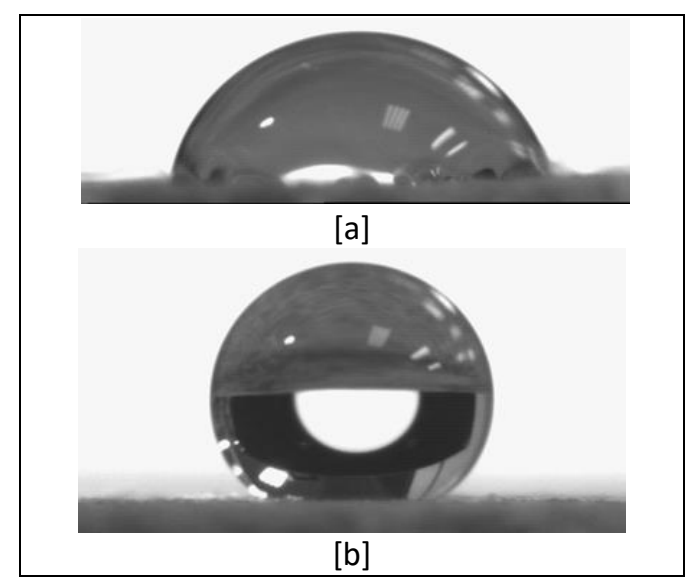

FIGURA 8: Ângulo de contato entre uma gota de água deionizada e [a] uma superfície de fibrocimento e [b] uma superfície de fibrocimento pintada com hidrofugantes.

FONTE: Autoria própria. 


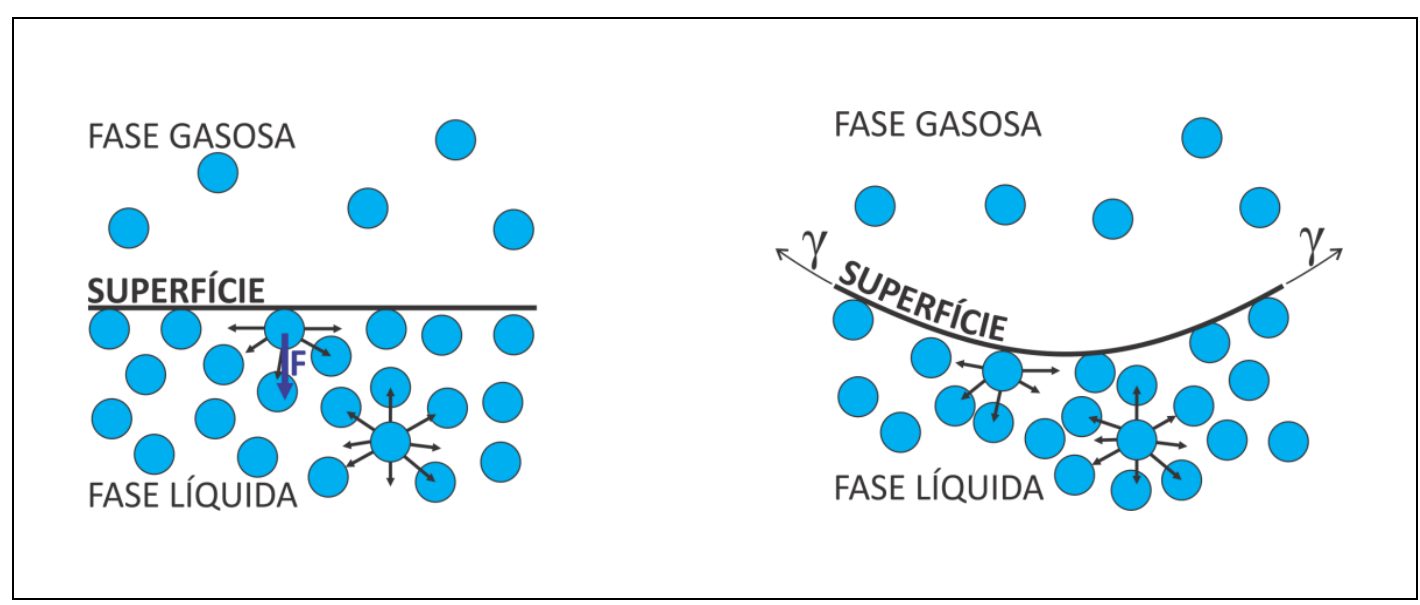

FIGURA 9: Forças que atuam nas moléculas de água na superfície com resultante na direção e sentido do interior da massa de água, e a tensão superficial $(\gamma)$ que tende a minimizar a área da superfície.

FONTE: Autoria própria.

Estes conceitos fundamentam o princípio da depressão capilar, que é a pressão existente dentro dos poros, que aumenta à medida que estes sofrem secagem, causando retração em escala macroscópica. Este fenômeno é descrito pela equação de Laplace (Equação 1), que expressa a relação entre a diferença de pressão nas fases líquida (água dentro do poro) e gasosa (ar dentro do poro e no meio ambiente), com a tensão superficial do líquido e os raios formados no menisco.

A equação de Laplace sustenta a base teórica para a equação de Kelvin, que descreve o efeito da curvatura da superfície na pressão de vapor da fase gasosa (BARNES, 2011). Assim, uma vez que a pressão de vapor está diretamente relacionada com a umidade relativa da fase gasosa, a equação de Kelvin descreve como esta umidade realtiva se reflete na pressão capilar atuante no poro. A dedução da equação de Kelvin parte da geometria existente na formação do menisco, envolvendo a tensão superficial e o ângulo de contato, e da equação de Laplace. A relação entre a pressão de vapor quando há um menisco formado, com a pressão de vapor quando a superfície é plana, está diretamente relacionada com a umidade relativa da fase gasosa, de modo que a equação de Kelvin pode ser expressa de duas formas, como mostra a Equação 2.

$$
\sigma=P_{G}-P_{L}=\gamma\left(\frac{1}{r_{1}}+\frac{1}{r_{2}}\right)
$$

Equação de Laplace, em que:

$\sigma$ : Pressão capilar $(\mathrm{N} / \mathrm{m})$;

$\boldsymbol{P}_{G}$ : Pressão na fase gasosa $(\mathrm{Pa})$;
$\boldsymbol{P}_{\mathbf{L}}$ : Pressão na fase líquida $(\mathrm{Pa})$;

$r$ : Tensão superficial do líquido $(\mathrm{N} / \mathrm{m})$;

$r_{1}$ e $r_{2}$ : Raios do menisco $(\mu \mathrm{m})$.

$$
\sigma=P_{L}-P_{G}=\frac{R T \rho}{V_{m}} \ln (H) \quad \text { Eq. [2] }
$$

\section{Equação de Kelvin, em que:}

$V m$ : Volume molar $\left(\mathrm{m}^{3}\right)$;

$\boldsymbol{R}$ : Constante universal do gás (287 J / K kg);

$T$ : Temperatura (K);

$\boldsymbol{\rho}$ : Densidade específica do líquido $\left(\mathrm{kg} / \mathrm{m}^{3}\right)$;

$\boldsymbol{H}$ : Umidade relativa da fase gasosa (\%).

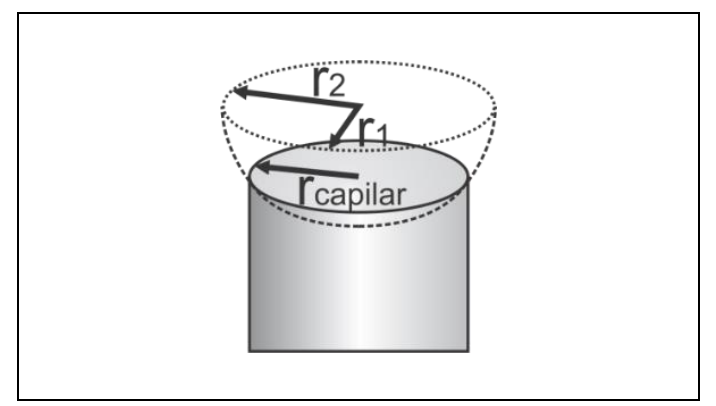

FIGURA 10: Indicação dos raios $r_{1}$ e $r_{2}$ do menisco formado no poro capilar. FONTE: Autoria própria.

Em resumo, o mecanismo de depressão capilar descreve a partir das equações de Laplace e Kelvin, como que as tensões geradas nos poros capilares são formadas e, desta forma, causam retração em escala macroscópica nos materiais cerâmicos, incluindo os compósitos cimentícios.

No Brasil, a ação da formação de gelo em materiais porosos não é crítica, uma vez que não há muitas regiões do país onde ocorre congelamento da água devido a baixas temperaturas. Na forma 
sólida (gelo), a água dilata-se em $9 \%$, causando tensões internas nas cerâmicas capazes de gerar fissuração.

O mesmo princípio ocorre quando a água transporta alguns tipos de sais solúveis para o interior dos materiais cerâmicos. Em alguns casos, dependendo da composição do material cerâmico, estes sais podem fazer parte da composição do material, e se solubilizar com o ingresso de água limpa no interior dos poros. A dissolução propriamente dita dos sais não é fator deletério para as cerâmicas, entretanto, quando estes cristalizam durante um processo de secagem, os sais no estado sólido podem causar expansão e tensões internas capazes de ocasionar fissuras no material. Por esse motivo é que algumas cerâmicas não resistem à ação constante de molhagem e secagem, pois estes ciclos de solubilização e cristalização de sais ocorrem repetidas vezes, até desagregar o material. A solução aquosa é formada no interior da peça cerâmica pelo contato entre a água e sais solúveis presentes no material, ou é oriunda de fontes externas e movimenta-se de uma parte a outra da estrutura através da rede de poros do material. Assim, as condições necessárias para que ocorra a formação desses depósitos são a coexistência de água, sais solúveis em água e condições ambientais e de estrutura que proporcionem a percolação e evaporação da água.

A evaporação da solução aquosa de sais pode ocorrer na superfície ou em regiões próximas a esta, apenas quando existe um gradiente de umidade entre a atmosfera ambiente e o material que favoreça este fenômeno. Entretanto, em ambientes de elevada umidade como porões, ou em presença de sais de difícil secagem, os sais não chegam a se cristalizar, depositando-se como um "gel", cuja viscosidade depende da composição e concentração da solução.

Florescências são depósitos salinos que se formam nas peças cerâmicas, sendo também a água o agente mobilizador dos sais solúveis. Segundo Menezes (2006), as florescências podem ser divididas em dois grandes grupos: subflorescências (criptoflorescências) e eflorescências. As subflorescências são florescências não visíveis, porque os depósitos salinos se formam sob a superfície da peça (no interior do material cristalização de sais), enquanto que nas eflorescências os depósitos salinos se formam na superfície dos produtos cerâmicos. A cristalização de sais na superfície das peças cerâmicas não produz esforços mecânicos importantes. Ao contrário, quando a cristalização se dá no interior do material, como foi dito anteriormente, podem ser produzidos esforços mecânicos consideráveis. Assim, as eflorescências causam degradação microestrutural apenas nas zonas próximas a superfície, bem como degradação estética no produto cerâmico, paredes pintadas, pisos e tetos. Os danos na aparência das construções intensificam-se quando há um contraste de cor entre os depósitos de sais e a alvenaria.

\subsubsection{Compósitos Cimentícios: concreto, argamassa, fibrocimento etc.}

Os compósitos são materiais multifásicos produzidos artificialmente para a obtenção das melhores propriedades de suas fases constituintes (matriz + fase dispersa). O concreto é um tipo de compósito que consiste em um agregado de partículas ligadas umas às outras pela pasta de cimento. No caso do concreto de cimento Portland, a fase agregada é constituída de areia e brita e a matriz pelo cimento e água (CALLISTER Jr. et al., 2008). Além do concreto, a argamassa e o fibrocimento também são compósitos cimentícios amplamente utilizados na construção.

Os compósitos cimentícios são materiais cerâmicos, denominados rochas artificiais, cujas propriedades são comuns às dos materiais cerâmicos, e que podem variar dentro de um grande intervalo, devido principalmente a diferenças de porosidade. Os materiais cerâmicos possuem elevada estabilidade química, dimensional e resistência mecânica. Porém, os compósitos cimentícios possuem duas particularidades que reduzem seu desempenho, que são: porosidade e fase hidratada solúvel do cimento (hidróxido de cálcio).

A porosidade é o canal de entrada de agentes agressivos como a água, sais solúveis, agentes reativos com as fases do cimento, microrganismos entre outros nos materiais porosos. 
A porosidade das argamassas e fibrocimentos é elevada, da ordem de 30 - 50\% (CARDOSO, 2009), enquanto que a dos concretos gira em torno dos 15\% (SATO e AGOPYAN, 1998). A movimentação dos agentes agressivos para o interior do compósito será governada pela continuidade dos poros, isto é, pela permeabilidade. Assim, um material pode apresentar porosidade elevada, mas se os poros forem descontínuos, a permeabilidade do material será baixa, impedindo o avanço dos agentes agressivos para o interior do material.

A permeabilidade dos compósitos cimentícios é controlada pela matriz de cimento hidratada. Dentre as fases hidratadas do cimento, as mais importantes são o silicato de cálcio hidratado (C-S-H ${ }^{\text {ver2}) ~ e ~ o ~ h i d r o ́ x i d o ~ d e ~ c a ́ l c i o, ~ t a m b e ́ m ~}$ denominado portlandita - $\mathrm{Ca}(\mathrm{OH})_{2}$. O C-S-H é a fase resistente que confere a maioria das propriedades do compósito cimentício, incluindo a resistência à ação da água. O hidróxido de cálcio é uma fase solúvel em água e suscetível à reação com o $\mathrm{CO}_{2}$ do ar, constituindo-se no principal desencadeador dos processos de deterioração dos compósitos cimentícios pela ação das variáveis atmosféricas. Por este motivo, os compósitos cimentícios sofrem efeitos específicos quando submetidos à ação das variáveis atmosféricas, como:

- degradação pela ação de sulfatos: os compósitos cimentícios são suscetíveis à ação destrutiva de meios aquosos contendo sulfatos; esta ação danosa é chamada de "ataque por sulfatos". O ataque por sulfatos está associado à interação de íons sulfatos com pasta de cimento hidratada, podendo se manifestar de várias formas, pois a origem dos íons sulfato pode ser tanto externa quanto interna. São exemplos de fontes de íons sulfatos a água do mar e o lençol freático (SOUZA, 2006).

O processo completo de deterioração do ataque por sulfatos envolve três etapas: (a) difusão dos íons agressivos para o interior da matriz cimentícia, que é função da porosidade e permeabilidade; (2) reações químicas entre o íon sulfato e certos constituintes hidratados do cimento (portlandita, monossulfoaluminato e outros aluminatos hidratados) formando espécies químicas que resultam em expansão (etringita e gipsita) e (c) fissuração da matriz, algumas vezes associada à reação química de descalcificação do $\mathrm{C}-\mathrm{S}-\mathrm{H}$, resultando em perda de resistência e desintegração. Paralelamente a este processo de deterioração pode ocorrer uma ação danosa oriunda da cristalização de sais. Irassar et al. (1996) concluíram que o mecanismo de ataque por sulfato de sódio pode ser dividido entre formação de etringita, formação de gipsita e cristalização de sais. Os compostos formados pela reação química de degradação ocupam mais espaço que os compostos originais, causando expansão, ruptura e fissuração. Conjuntamente a este efeito, os sais de sulfatos cristalizados também ocupam mais espaço na matriz cimentícia do que dissolvidos.

- Corrosão da armadura das estruturas de concreto armado pela ação de cloretos: um dos principais processos de deterioração das estruturas de concreto armado é o ingresso de íons cloreto, que conduzem a corrosão do aço (armadura) e uma subsequente redução na estética, resistência e vida útil. Isso pode levar à reparação ou substituição prematura da estrutura.

Os cloretos nos concretos podem ter como fontes os agregados, o solo ou água contaminados, o aditivo acelerador de pega à base de cloretos, os sais de degelo ou a água do mar. Entretanto, independente da origem, os cloretos podem ser encontrados nos concretos de duas formas (PEREIRA e CINCOTTO, 2001): como cloreto livre, solúvel ou dissociável, na forma de íon na água dos poros e como cloreto combinado, formando parte das fases hidratadas do cimento. O primeiro tratase do cloreto realmente agressivo à armadura e o segundo, geralmente, se encontra combinado na forma de cloroaluminato conhecido como sal de Friedel. Os compostos anidros de aluminato e ferroaluminato de cálcio, $\mathrm{C}_{3} \mathrm{~A}$ e $\mathrm{C}_{4} \mathrm{AF}$, presentes no cimento são capazes de fixar quimicamente os cloretos, na forma de cloroaluminatos (JUCÁ et al., 2002). Embora o cloreto seja solúvel em água, o que

\footnotetext{
${ }^{2} \times \mathrm{CaO} \cdot \mathrm{SiO}_{2} \cdot \mathrm{yH}_{2} \mathrm{O}$ silicato de cálcio hidratado
} 
pode causar corrosão, é conveniente determinar os cloretos totais (soma do cloreto livre e o combinado), pois parte dos combinados podem ficar disponíveis para reações deletérias devido a fenômenos como carbonatação do concreto ou elevação de temperatura.

Absorção capilar, permeabilidade e difusão são os meios pelos quais os íons cloreto podem penetrar no concreto. No caso da difusão, é preciso que o concreto esteja saturado, para que haja uma fase líquida constante. O movimento dos íons ocorre devido a um gradiente de concentração. O mecanismo de ingresso de cloretos por permeabilidade é proveniente de gradientes de pressão. O método de transporte mais comum é a absorção e ocorre devido ao fenômeno da sucção capilar. Já a absorção é oriunda de gradientes de umidade. Os mecanismos de corrosão dos materiais metálicos serão discutidos na seção 3.2.

- Eflorescências devido à dissolução da portlandita: a formação de eflorescências já foi discutida anteriormente e está associada à dissolução e a cristalização de sais solúveis nos materiais cerâmicos. Nos materiais cimentícios, as eflorescências ocorrem devido à lixiviação do hidróxido de cálcio e, posteriormente, a sua solubilização na superfície do material.

- Carbonatação: a carbonatação dos compósitos cimentícios é uma ação deletéria que causa retração do material, resultado em tensão interna e consequente fissuração. Além disso, também ocorre a redução do $\mathrm{pH}$ da matriz cimentícia, que no caso do concreto armado é causa de despassivação da armadura, que fica suscetível à oxidação e corrosão. A carbonatação é um processo de descalcificação, no qual o hidróxido de cálcio e o C-S-H perdem o cálcio de sua composição através de uma reação química; ocorre pela reação destes produtos do cimento já hidratado, o hidróxido de cálcio $\left(\mathrm{Ca}(\mathrm{OH})_{2}\right)$, com o dióxido de carbono $\left(\mathrm{CO}_{2}\right)$ presente no ar, resultando no carbonato de cálcio mais água $\left(\mathrm{Ca}(\mathrm{OH})_{2}+\mathrm{CO}_{2} \rightarrow \mathrm{CaCO}_{3}+\mathrm{H}_{2} \mathrm{O}\right]$. Esta reação tem relação com a umidade do ar e incidência direta da água por precipitação, além da exposição ao $\mathrm{CO}_{2}$ do ar, no caso do material cimentício não estar revestido.

O mecanismo de carbonatação necessita de água, uma vez que acontece a interação do dióxido de carbono com os compostos hidratados do cimento que ocorre na solução intersticial (HOST e WITTMANN, 2002). Na presença de umidade, o anidrido carbônico difunde na estrutura porosa do material cimentício e dissolve na solução dos poros, produzindo íons $\mathrm{CO}_{3}^{-2}$ (TAYLOR, 1997). Estes por sua vez, combinam com o íon $\mathrm{H}^{+}$, proveniente da hidrólise da água, formando ácido carbônico $\left(\mathrm{H}_{2} \mathrm{CO}_{3}\right)$ (HOPPE FILHO, 2008). De forma simplificada, o ácido carbônico reage com hidróxido de cálcio para formar carbonato de cálcio. Uma vez que no balanço final da reação, uma molécula de dióxido de carbono substitui uma molécula de água, a massa do compósito aumenta, já que peso molecular do dióxido de carbono $(44,01 \mathrm{~g} / \mathrm{mol})$ é substancialmente maior do que 0 da água (18,02 g/mol) (PERSSON, 2002).

Além do hidróxido de cálcio, a decomposição de outros compostos hidratados do cimento ocorre simultaneamente, como a etringita, o monossulfoaluminato, a hidrogranada (aluminato de cálcio hidratado) e o C-S-H (HOPPE FILHO, 2008; HOUST et al., 2002). A reação que causa retração em escala macroscópica é a descalcificação do $\mathrm{C}-\mathrm{S}-\mathrm{H}$, que tem sua relação $\mathrm{Ca} / \mathrm{Si}$ reduzida até formar carbonato de cálcio e sílica gel.
$\mathrm{CO}_{2}+\mathrm{H}_{2} \mathrm{O} \rightarrow \mathrm{H}_{2} \mathrm{CO}_{3}$

$2 \mathrm{H}_{2} \mathrm{CO}_{3}+\mathrm{Ca}(\mathrm{OH})_{2} \rightarrow \mathrm{Ca}\left(\mathrm{HCO}_{3}\right)_{2}+2 \mathrm{H}_{2} \mathrm{O}$ $\mathrm{Ca}\left(\mathrm{HCO}_{3}\right)_{2}+\mathrm{Ca}(\mathrm{OH})_{2} \rightarrow 2 \mathrm{CaCO}_{3}+2 \mathrm{H}_{2} \mathrm{O}$ formação de ácido carbônico carbonatação do hidróxido de cálcio .carbonatação do bicarbonato de cálcio

EQUAÇÃO 3: Reações químicas envolvidas no processo de carbonatação. 


\subsection{MATERIAIS DE CONSTRUÇÃO METÁLICOS}

Os materiais metálicos são bastante utilizados na construção. Estes materiais podem ser utilizados em peças estruturais (armadura do concreto e perfis estruturais) e para fins nãoestruturais como: esquadrias e metais sanitários. Os metais também são muito utilizados para cabeamento elétrico e lógico, assim como podem ser aplicados para desempenhar funções estéticas, como revestimento (chapas galvanizadas corrugadas, placas de aço patinável, chapas de aço inox).

Os metais podem ser divididos em dois grandes grupos: materiais metálicos ferrosos e materiais metálicos não-ferrosos. Os ferrosos são compostos por ligas metálicas onde o ferro é o principal elemento. Este material é amplamente utilizado na construção civil em virtude da abundância com que se encontra no planeta, a facilidade de fabricação das ligas, baixo custo, variedade de propriedades mecânicas e a versatilidade de aplicações. São exemplos de metais ferrosos: o aço, o ferro fundido e o ferro laminado. Nestas composições é possível adicionar elementos como: silício, manganês, fósforo, cobre, enxofre em concentrações normalmente inferiores a $1 \%$. Através do processo de fabricação (incluindo a composição da liga e tratamentos térmicos) é possível melhorar as condições de resistência mecânica do material. As principais limitações da utilização deste tipo de metal são: a alta densidade, condutibilidade elétrica baixa em comparação com outros metais e a suscetibilidade à corrosão.

De acordo com a necessidade de uso, fazse necessário dispor de metais ou ligas metálicas capazes de atender determinadas situações. Neste sentido, os metais não ferrosos podem contribuir adequando-se à necessidade. Metais não ferrosos são metais, que, como o próprio nome já especifica não contém ferro em sua composição. São exemplos de metais não ferrosos, o zinco, o cobre, o alumínio, o bronze e chumbo. Estes metais possuem boa condutibilidade elétrica, térmica, grande resistência à corrosão eletrolítica e baixa densidade; a composição das ligas confere grande variedade de propriedades e aplicações, sendo viável a sua aplicação com função estrutural, em alguns casos.

De modo geral, os metais resistem bem às influências atmosféricas já que não possuem porosidade. Desta forma, não são suscetíveis aos mecanismos de degradação atuantes nas cerâmicas. No entanto, os metais não possuem a mesma estabilidade química das cerâmicas, uma vez que a mobilidade dos elétrons livres facilita a ocorrência de reações químicas deletérias, que resultam em corrosão. Diferentemente do observado nos materiais cerâmicos, a ação de deterioração pelas variáveis atmosféricas causa nos metais uma perda efetiva de material ou gera uma camada de material não-metálico sobre a peça que está em processo de deterioração (CALLISTER Jr et al., 2008). A corrosão consiste na deterioração dos materiais pela ação química ou eletroquímica do meio, podendo estar ou não associada a esforços mecânicos. São ambientes corrosivos: a atmosfera, soluções aquosas, solos, ácidos, bases, solventes inorgânicos, sais fundidos, metais líquidos e até o corpo humano. Dentre os ambientes corrosivos listados, o que atuam mais fortemente na durabilidade dos metais são: a umidade do ar contendo oxigênio dissolvido e a precipitação, sendo que em ambas atuam como fonte de água para a ocorrência de corrosão, como mostra a Figura 11.

Os processos de corrosão podem ser classificados em eletroquímicos (corrosão aquosa) e corrosão química ou oxidação. Ao se considerar o emprego de materiais de construção, é necessário que estes resistam à ação do meio corrosivo.

Devido às suas excelentes propriedades condutoras de eletricidade, os metais podem ser parcialmente dissolvidos em ambientes aquosos ou úmidos, perdendo parte de sua estrutura e tornando-se menos resistentes. A corrosão torna-se mais intensa em ambientes próximos ao oceano, pelo teor de sais existentes na atmosfera marinha. A corrosão depende de fatores como a composição química do metal, do ambiente aquoso e da temperatura. Dependendo da intensidade, a corrosão diminui a vida útil do material metálico devido à redução de suas propriedades mecânicas. Os processos corrosivos de natureza eletroquímica apresentam mecanismos idênticos, pois sempre 
serão constituídos por áreas anódicas e catódicas, entre as quais circula uma corrente de elétrons e uma corrente de íons.

A corrosão aquosa dos metais ocorre quando átomos metálicos se dissolvem como íons em meio aquoso. Como isso ocorre quando metais dessemelhantes ${ }^{3}$ são colocados em contato elétrico na presença de um eletrólito, diz-se que a corrosão é de natureza eletrolítica. No processo eletrolítico há uma transferência de elétrons de um componente químico para outro. Os átomos metálicos perdem ou cedem elétrons na chamada reação de oxidação. A Tabela 1 resume os tipos de corrosão em metais.
A oxidação representa a reação química direta entre o metal e o oxigênio atmosférico. As reações de oxidação consistem na perda de elétrons da camada de valência dos átomos do metal, ao mesmo tempo que os íons metálicos resultantes podem ir para a solução corrosiva ou formar um composto insolúvel. Há vários mecanismos para o acúmulo de óxidos na superfície dos metais. Em alguns metais, o revestimento de óxidos é brando e fornece proteção contra ataques ambientais; já em outros, o revestimento tende a apresentar falhas e não culmina em uma proteção efetiva.

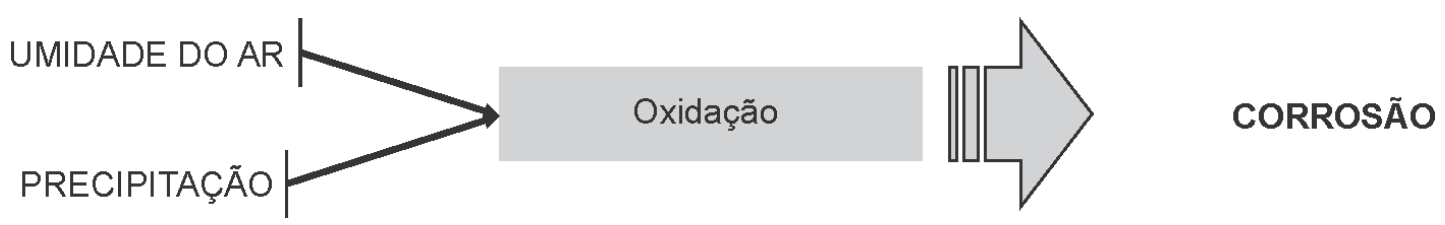

FIGURA 11: Ação das variáveis atmosféricas no desempenho dos materiais metálicos. FONTE: Autoria própria.

\begin{tabular}{|c|c|}
\hline Tipo de corrosão & Causa \\
\hline Corrosão uniforme & $\begin{array}{l}\text { Ataque sobre a superfície da peça metálica que está em contato com o meio } \\
\text { corrosivo. Há uma consequente perda de espessura da peça. }\end{array}$ \\
\hline Corrosão por pites & $\begin{array}{l}\text { Corrosão em pontos localizados da superfície - há formação de cavidades nos } \\
\text { locais em contato com o meio corrosivo }\end{array}$ \\
\hline Corrosão galvânica & $\begin{array}{l}\text { Ocorre quando há contato elétrico, em meio aquoso ou úmido, entre dois } \\
\text { metais de características reativas diferentes. Nesse caso, o metal menos } \\
\text { nobre, ou mais eletronegativo, atuará como ânodo e se corroerá, fornecendo } \\
\text { elétrons, enquanto que o metal mais nobre, mais inerte, atuará como cátodo } \\
\text { recebendo elétrons. }\end{array}$ \\
\hline Corrosão em frestas & $\begin{array}{l}\text { Frestas são defeitos nos metais e podem ser locais preferenciais para o início } \\
\text { de um processo de corrosão. Estes locais estão sujeitos à formação de pilhas } \\
\text { de aeração diferencial e concentração iônica diferencial, dependendo do } \\
\text { meio (aquoso ou gasoso). A progressão da corrosão parte das bordas para o } \\
\text { interior da mesma. }\end{array}$ \\
\hline \multicolumn{2}{|l|}{ Corrosão seletiva de fases: } \\
\hline Corrosão intergranular & $\begin{array}{l}\text { Ocorre quando existe um caminho preferencial para a corrosão entre os } \\
\text { grãos que compõem a microestrutura do metal. Pode ocorrer na presença ou } \\
\text { não de uma tensão aplicada. }\end{array}$ \\
\hline \multicolumn{2}{|l|}{ Corrosão transgranular: } \\
\hline $\begin{array}{l}\text { Corrosão por escoamento de } \\
\text { fluidos }\end{array}$ & $\begin{array}{l}\text { Ocorre o desgaste da peça metálica pelo atrito ou fricção de sua superfície } \\
\text { com o escoamento de fluidos - processo de abrasão. }\end{array}$ \\
\hline Corrosão por turbulência & $\begin{array}{l}\text { Processo corrosivo também causado pela interação da superfície do metal } \\
\text { com fluxo turbulento de um líquido. }\end{array}$ \\
\hline
\end{tabular}

FONTE: Autoria própria.

\footnotetext{
3 O termo "dessemelhante" indica que ocorrem diferentes variações de energia livre quando quantidades equivalentes de cada metal são ionizadas e dissolvidas no meio ambiente. A dessemelhança pode ocorrer em função da concentração de
}

íons no meio ambiente, da resistividade do eletrólito, da microestrutura dos metais, das tensões existentes e das películas superficiais existentes. 
As medidas de prevenção ou redução do processo de corrosão nos metais passa pela escolha dos materiais, adequação/conhecimento do ambiente onde será utilizado, uso de inibidores sobre a superfície dos metais, verificações de projeto e aplicação de proteção sobre as superfícies metálicas.

Seja qual for o tipo de processo corrosivo atuante há um comprometimento da vida útil do material. Considerando estas possibilidades, fica evidente a importância da análise do local de utilização do material bem como sua adequação aos condicionantes atmosféricos existentes. Existem muitas formas de recuperação de estruturas metálicas, porém são onerosas e necessitam de manutenção constante. Buscas por metodologias preventivas são sustentáveis, pois incrementam a vida útil das edificações e reduzem a necessidade de substituição do material empregado.

\subsection{MATERIAIS DE CONSTRUÇÃO POLIMÉRICOS}

Os materiais poliméricos são utilizados na construção devido a sua versatilidade na aplicação, propriedades específicas e baixo custo. Entre os elementos poliméricos utilizados na construção, destacam-se os tubos de PVC utilizados em instalações hidráulicas, os conduítes elétricos de PVC, forros, telhas, placas acrílicas transparentes, entre outros. As principais limitações da utilização deste tipo material são: a resistência mecânica, que impossibilita algumas aplicações estruturais, e a durabilidade, uma vez que não possuem elevada estabilidade.

Diferente dos materiais cerâmicos e metálicos, a água não costuma ser o agente agressivo preponderante dos materiais poliméricos. A reduzida estabilidade das suas ligações químicas faz com que os polímeros se alterem estruturalmente quando expostos a elevadas temperaturas. Deste modo, as variáveis atmosféricas: radiação solar e temperatura do ar são os agentes mais severos na redução da vida útil dos elementos poliméricos (Figura 12).
A degradação de materiais poliméricos expostos ao ambiente tende a ocorrer devido à ação combinada da radiação ultravioleta, do calor e do oxigênio atmosférico. Diferente do que acontece nos metais, cuja corrosão tem causas eletroquímicas, a degradação nos polímeros ocorre por processos de natureza físico-química. Além disso, é possível uma ampla variedade de reações e consequências adversas para a desagregação polimérica (CALLISTER Jr et al., 2008).

Os polímeros podem sofrer degradação por meio de rompimento das ligações moleculares, causando diminuição do peso molecular. Como existe uma relação forte entre o peso molecular e as propriedades dos materiais poliméricos, as rupturas das ligações da cadeia molecular reduzem a resistência mecânica e química dos polímeros. A ruptura das ligações pode ocorrer devido à exposição ao calor, às radiações ou alguns agentes químicos.

A estabilidade térmica dos polímeros está intimamente ligada à magnitude das ligações químicas que formam seus compostos. Quando um composto recebe radiação (raios $\alpha$, raios $\beta$, raios $\gamma$ e radiação ultravioleta), os elétrons das camadas mais externas interagem com a radiação, podendo ser removidos da camada orbital de um determinado átomo. Este átomo, então, se ioniza, alterando a estrutura molecular $e$ as características originais do polímero. Consequentemente, uma das ligações covalentes do átomo é rompida, ocorrendo um rearranjo de átomos ou grupos de átomos.

Os polímeros são fortemente degradados pela ação do oxigênio, no entanto, estas reações deletérias estão associadas aos processos que envolvem alta temperatura ou incidência de radiação solar. Alguns processos de degradação são: a foto-oxidação, termo-oxidação, ação química devido a poluentes e microrganismos etc. Estes processos de degradação envolvem basicamente a absorção da radiação ultravioleta e reações de oxidação. 


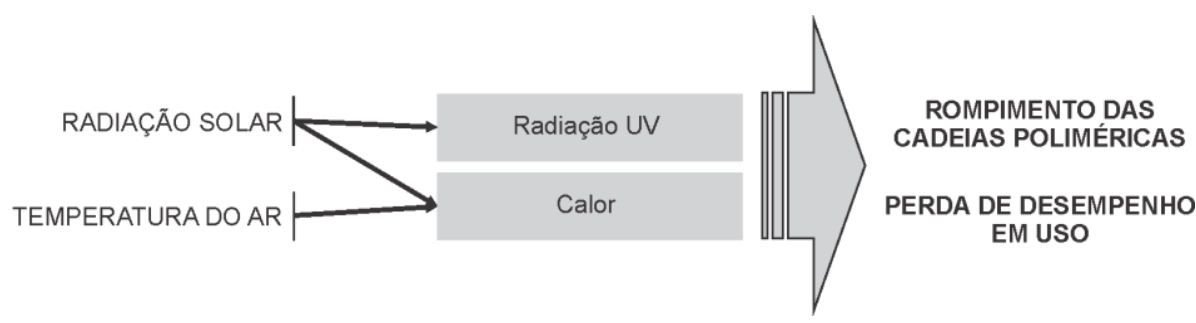

FIGURA 12: Ação das variáveis atmosféricas no desempenho dos materiais poliméricos. FONTE: Autoria própria.

\subsection{MADEIRAS COMO MATERIAL DE CONSTRUÇÃO}

As madeiras, utilizadas na construção, podem ser classificadas como materiais poliméricos naturais, de modo que os processos de degradação devido à incidência de radiação UV e calor, que ocorrem nos polímeros, também são nocivos à madeira. A natureza biológica da madeira torna este material único, com propriedades bem específicas e susceptíveis a ações de degradação específicas pelas variáveis atmosféricas. Existem vários agentes e mecanismos de degradação da madeira, tais como: os microrganismos (fungos, mofo e insetos), os agentes oxidantes, a decomposição térmica e a ação física e química devido ao intemperismo. Dessa forma, praticamente todas as variáveis atmosféricas são nocivas à madeira (Figura 13).

A ação das variáveis atmosféricas pode causar degradação física e química da madeira. A deterioração física provoca mudanças de cor, aspereza superficial, rachaduras e fissuras, enquanto que a deterioração química é um fenômeno superficial oriundo da sequência de reações com os radicais livres, rompimento da estrutura da lignina, o que também causa a mudanças de cor. Os fatores que afetam a madeira quando exposta às variáveis atmosféricas são a radiação solar (raios UV e luz visível), a umidade do ar, precipitação, temperaturas elevadas (que aumenta a velocidade das reações) e a chuva ácida associada à alta concentração de dióxido de enxofre.

A madeira, quando exposta ao ambiente sem nenhuma proteção, tende a escurecer. Contudo, os efeitos das variáveis atmosféricas normalmente limitam-se a sua superfície. Deve-se considerar que a erosão da madeira pela exposição ao ambiente é muito lenta (0,0025 polegada/ano). Essa erosão aumenta em atmosferas poluídas com a presença de dióxido de enxofre, levando à degradação física e química da madeira quando exposta aos elementos naturais e à chuva ácida.

Os insetos são responsáveis por grande parte da degradação da madeira. Os cupins são os que mais afetam a integridade deste material. Tais insetos atacam as madeiras que tiverem condições favoráveis para sua proliferação. Para algumas espécies de cupins, a umidade elevada é uma condição favorável para sua proliferação (cupins de madeira úmida), enquanto que para outras espécies, a condição propícia para proliferação é em níveis de umidade em torno de 10 a $12 \%$ (cupins de madeira seca), que é o nível usual de umidade de aplicação e uso da madeira.

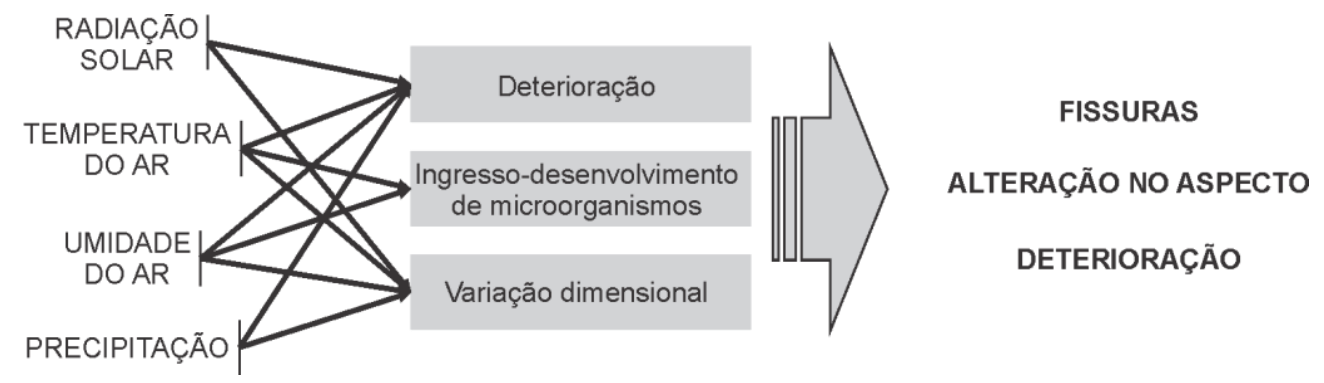

FIGURA 13: Ação das variáveis atmosféricas no desempenho dos materiais poliméricos. FONTE: Autoria própria. 


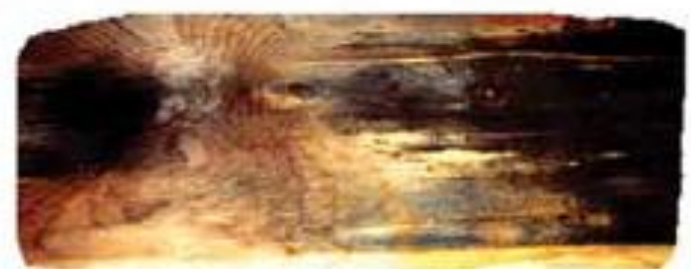

[a]

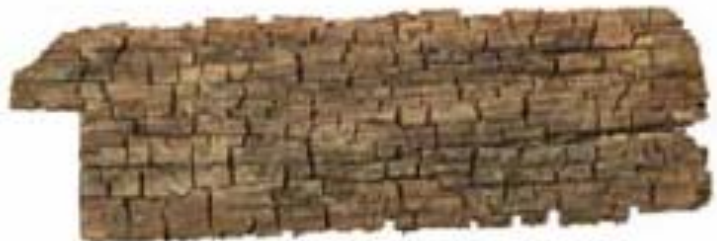

[b]

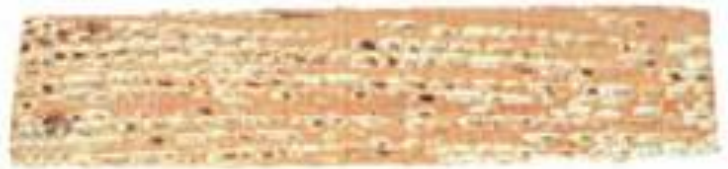

[c]

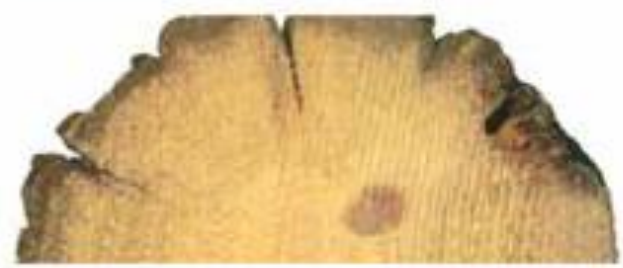

[d]

FIGURA 14: Amostras representativas de quatro tipos comuns de crescimento de fungos em madeira: [a] descoloração; [b] apodrecimento de pinho; [c] apodrecimento em mapa - manchas brancas e [d] apodrecimento de pinho com tratamento preservativo. FONTE: FOREST PRODUCT LABORATORY, 2010.

Os fungos precisam de condições mais específicas para sua proliferação, sofrendo influência da temperatura, umidade e $\mathrm{pH}$ da madeira, para se formarem. Com relação à temperatura do ar, a condição ideal para o desenvolvimento dos fungos é entre $25^{\circ} \mathrm{C}$ e $30^{\circ} \mathrm{C}$; entretanto o ataque por fungos pode ocorrer em uma faixa mais ampla de temperatura, de $0^{\circ} \mathrm{C}$ a $40^{\circ} \mathrm{C}$. Em relação ao grau de umidade, os fungos necessitam que a madeira se encontre em níveis de umidade acima do usual de aplicação e uso, em torno de $20 \%$. Mas este valor pode variar, em função da densidade da madeira, uma vez que a condição ideal para a ocorrência de fungos é no ponto de saturação das fibras. $\mathrm{O}$ pH também é um fator importante par ao desenvolvimento de fungos, sendo a faixa ideal para a sua formação e proliferação entre 2 e 7 (SCANAVA Jr. e GARCIA, 2004). Os fungos podem degradar a madeira, ou somente alterar o aspecto superficial. A Figura 14 apresenta amostras representativas de quatro tipos comuns de crescimento de fungos na madeira.

\section{CONCLUSÕES}

Esse estudo teve como objetivo apresentar uma compilação do conhecimento sobre a influência das variáveis atmosféricas nos materiais da construção civil: cerâmicos, metálicos, poliméricos e madeiras. Com relação aos materiais cerâmicos, destaca-se que a radiação solar e temperatura do ar são as variáveis atmosféricas que mais influenciam a durabilidade das cerâmicas pelo efeito de dilatação e retraimento dos componentes da cerâmica. Já os metais, como não possuem porosidade, não são susceptíveis às variáveis descritas. Por outro lado, como os metais não possuem a mesma estabilidade química das cerâmicas, sofrem com a corrosão que é propiciada tanto pela umidade atmosférica quanto pela precipitação. Nos materiais poliméricos, a água não costuma ser o agente agressivo preponderante. A reduzida estabilidade das suas ligações químicas faz com que os polímeros se alterem estruturalmente quando expostos a elevadas temperaturas. Deste modo, as variáveis atmosféricas: radiação solar e temperatura do ar são os agentes mais severos na redução da vida útil dos elementos poliméricos. Por fim, as madeiras são susceptíveis à degradação por praticamente todas as variáveis atmosféricas. Por exemplo, a variação de umidade e temperatura do ar favorecem o desenvolvimento de microrganismos (fungos, mofo e insetos) que podem degradar fisicamente a madeira.

\section{REFERÊNCIAS BIBLIOGRÁFICAS}

ABNT, ASSOCIAÇÃO BRASILEIRA DE NORMAS TÉCNICAS. NBR15575 - Edificações Habitacionais - Desempenho. 2013.

AGOPYAN, V.; JOHN, V.M.; O desafio da sustentabilidade na construção civil. São Paulo: Blucher; 2011.

ANDRADY, A.L.; HAMID, H.S.; TORIKAI, A.; Effects of climate change and UV-B on materials. Photochem Photobiol Sci., 2(1):68-72. 2003. 
BARNES, G.; Interfacial science: an introduction. 2nd ed ed. Oxford ; New York: Oxford University Press, 2011.

BRUSAMARELLO, V.J. et al.; "Spatial interactions among localized corrosion sites", Journal of Electrochemical Society, v. 149, n. 5, pp. B163 - B173, 2002.

CALLISTER JR; WILLIAM D; SOARES, S.M.S.; Ciência e engenharia de materiais uma introdução. Rio de Janeiro: Livros Técnicos e Científicos, 2008.

CARDOSO, F.A.; Método de formulação de argamassa de revestimento baseado em distribuição granulométrica e comportamento reológico. São Paulo: Escola Politécnica da Universidade de São Paulo, 2009.

CIB W80/RILEM 71-PSL. Prediction of service life of building materials and components. In: CONSEIL INTERNATIONAL DU BÁTMENT POUR LA RECHERCHE L'ÉTUDE ET LA DOCUMENTATION E RÉUNION INTERNACIONALE DES LABORATOIRES D'ESSAIS ET DE RECHERCHES SUR LES MATÉRIAUX ETLES CONSTRUCTIONS. Rotterdam: CIB, RILEM, 1983.

FOREST PRODUCTS LABORATORY. Wood handbookWood as an engineering material. General Technical Report FPL-GTR-190. Madison, WI: U.S. Department of Agriculture, Forest Service, Forest Products Laboratory. 508 p. 2010.

HOPPE FILHO, J.; Sistemas cimento, cinza volante e cal hidratada: mecanismo de hidratação, microestrutura e carbonatação de concreto. São Paulo: Escola Politécnica da Universidade de São Paulo, 2008.

HOUST, Y.F.; WITTMANN, F.H.; Depth profiles of carbonates formed during natural carbonation. Cement and Concrete Research, v. 32, n. 12, p. 1923-1930, dez. 2002.

IDIART, A.E.; Coupled analysis of degradation processes in concrete specimens at the meso-level. Barcelona: Universitat Politècnica de Catalunya, 2009.

IRASSAR, E.F.; MAIO, A. DI.; BATIC, O.R.; Sulfate attack on concrete with mineral admixtures, Cement and Concrete Research. 26(1):113-123. 1996.

ISAIA, G.C.; Materiais de Construção Civil e Princípios de Ciência e Engenharia de Materiais. 2. ed. São Paulo: Ibracon, 2007.

JUCÁ, T.R.P.; SELMO, S.M.S.; FIGUEIREDO, E.P.; Avaliação da capacidade de certos cimentos brasileiros na combinação de cloretos através do método colorimétrico. 44ㅇ Congresso brasileiro do concreto. Belo Horizonte : IBRACON. 2002.

LIOU, K. N. An Introduction to Atmospheric Radiation. $2^{\text {nd }}$ Ed., Academic Press, 2002.

MENEZES, R.R. et al.; Sais solúveis e eflorescência em blocos cerâmicos e outros materiais de construção revisão. Cerâmica, v.52, n.321, São Paulo, 2006.
MINDESS, S.; Concrete. Englewood Cliffs, N.J: PrenticeHall, 1981.

MITIDIERI FILHO, C.V.; Qualidade e Desempenho na Construção Civil. In: Materiais de Construção Civil e Princípios de Ciência e Engenharia de Materiais. 1. ed. São Paulo: Instituto Brasileiro do Concreto IBRACON, 2007. v. 1p. $37-74$.

PERSSON, B.; Eight-year exploration of shrinkage in highperformance concrete. Cement and Concrete Research, v. 32, n. 8, p. 1229-1237, ago. 2002.

PEREIRA, L.F.L.C.; CINCOTTO, M.A.; BT/PCC/294: Determinação de cloretos em concreto de cimento Portland: Influência do tipo de cimento. Boletim técnico da Escola Politécnica da USP. São Paulo: EPUSP. 2001.

RIEDER, E.S. et al.; Revista Matéria, v. 14, n. 3, pp. $1000-$ 1014, 2009.

SATO, N.M.N.; AGOPYAN, V.; Análise da porosidade e de propriedades de transporte de massa em concretos. Boletim Técnico da Escola Politécnica da USP, v. 216, 1998.

SCANAVA JR, L.; GARCIA, J.N.; Determinação das propriedades físicas e mecânicas da madeira de Eucalyptus urophylla. Scientia Forestalis. Piracicaba, n.65, p. 120-129, 2004.

SOUZA, R.B.; Suscetibilidade de pastas de cimento ao ataque por sulfatos - Método de ensaio acelerado. São Paulo: Escola Politécnica da Universidade de São Paulo, 2006.

SOUZA, R.B. DE.; Estudo da retração em fibrocimento reforçado com fibra polimérica. São Paulo: Escola Politécnica da Universidade de São Paulo, 2014.

TAYLOR, H.F.W.; Cement chemistry. 2nd ed. ed. London: T. Telford, 1997. 